\title{
KORELASI ANTARA KEMAMPUAN BERPIKIR KRITIS DENGAN PENGUASAAN KOMPETENSI INTI PENGETAHUAN IPS SISWA
}

\author{
I Km. Agus Mudita ${ }^{1}$, DB. Kt. Ngr. Semara Putra ${ }^{2}$, I Wyn. Sujana ${ }^{3}$ \\ 1,2,3 Jurusan Pendidikan Guru Sekolah Dasar, Fakultas IImu Pendidikan \\ Universitas Pendidikan Ganesha \\ Singaraja, Indonesia \\ e-mail: komang.agus.mudita@undiksha.ac.id ${ }^{1}$, semara.putra@undiksha.ac.id ${ }^{2}$, \\ iwayan.sujana@undiksha.ac.id ${ }^{3}$
}

\begin{abstract}
Abstrak
Penelitian ini bertujuan untuk mengetahui korelasi yang signifikan antara kemampuan berpikir kritis dengan penguasaan kompetensi inti pengetahuan IPS siswa kelas V SD Gugus Ir. Soekarno Kecamatan Denpasar Selatan tahun pelajaran 2017/2018. Penelitian ini adalah penelitian ex post facto dengan jenis korelasional. Populasi dari penelitian ini adalah seluruh siswa kelas V SD Negeri yang ada di Gugus Ir. Soekarno Kecamatan Denpasar Selatan tahun pelajaran 2017/2018 yang berjumlah 325 orang siswa. Sampel ditentukan dengan menggunakan teknik proportional random sampling sehingga didapatkan sampel berjumlah 169 orang siswa. Data kemampuan berpikir kritis dikumpulkan dengan memberikan tes uraian kepada sampel, sedangkan data penguasaan kompetensi inti pengetahuan IPS dikumpulkan melalui pencatatan dokumen. Uji prasyarat menggunakan uji normalitas sebaran data dengan rumus chi-kuadrat. Setelah uji prasyarat terpenuhi, dan data berdistribusi normal, data dianalisis dengan teknik analisis korelasi product moment. Berdasarkan hasil analisis data didapatkan $r_{\mathrm{xy}}$ hitung $=0,342$, sedangkan $r_{x y}$ tabel pada taraf signifikansi $5 \%$ dengan $N=169$ diperoleh nilai $=0,148$. Karena $r_{x y}$ hitung $>r_{x y}$ tabel, maka hipotesis nol $\left(H_{0}\right)$ yang menyatakan tidak terdapat korelasi yang signifikan antara kemampuan berpikir kritis dengan penguasaan kompetensi inti pengetahuan IPS siswa kelas V SD Gugus Ir. Soekarno Kecamatan Denpasar Selatan tahun pelajaran 2017/2018 ditolak dan hipotesis alternatif $\left(\mathrm{H}_{\mathrm{a}}\right)$ diterima. Berdasarkan hasil penelitian tersebut dapat disimpulkan bahwa terdapat korelasi yang signifikan antara kemampuan berpikir kritis dengan penguasaan kompetensi inti pengetahuan IPS siswa kelas V SD Gugus Ir. Soekarno Kecamatan Denpasar Selatan tahun pelajaran 2017/2018.
\end{abstract}

Kata-kata kunci: kemampuan berpikir kritis, kompetensi pengetahuan IPS

\begin{abstract}
This study aims to determining the significant correlation between the ability of criticall thinking with the mastery of social sciences knowledge core competency of $5^{\text {th }}$ grade students of SD Gugus Ir. Soekarno South Denpasar Sub-district in the academic year 2017/2018. This study is ex post facto research, with correlational type. The population of this study was all students of $5^{\text {th }}$ grade of SD Negeri in Gugus Ir. Soekarno South Denpasar Sub-district academic year 2017/2018 which amounted to 325 students. The samples were determined by proportional random sampling technique so that the sample of 169 students. The data of critical thinking ability was collected by giving the test description to the sample, while the data of mastering of social sciences knowledge core competency was collected through document recording. The prerequisite test used the normality test of data distribution with the chi-square formula. After the prerequisite test is met, and the data was normally distributed, the data is analyzed by product moment correlation analysis technique. Based on the results of data analysis obtained $r_{x y}$ count $=$ 0.342 , while $r_{x y}$ table at $5 \%$ significance level with $N=169$ obtained value $=0.148$. Because $r_{x y \text { count }}>r_{x y}$ table, the null hypothesis $\left(H_{0}\right)$ which states there is no significant correlation between the ability of criticall thinking with the mastery of social science knowledge core competency of $5^{\text {th }}$ grade students of SD Gugus Ir. Soekarno, South Denpasar Sub-district in the academic year 2017/2018 was rejected and alternative hypothesis (Ha) was
\end{abstract}


accepted. Based on the results of this study can be concluded that there is a significant correlation between the ability of criticall thinking with with the mastery of social sciences knowledge core competency of $5^{\text {th }}$ grade students of SD Gugus Ir. Soekarno South Denpasar Sub-district in the academic year 2017/2018.

Keywords: critical thinking ability, social science knowledge competency

\section{Pendahuluan}

Untuk melahirkan siswa yang berkualitas perlu dilakukan dengan

melaksanakan kegiatan belajar yang baik. Belajar merupakan sebuah aktivitas akal yang sangat vital dan terjadi secara kompleks. Akal merupakan sebuah kelebihan manusia yang membedakannya dengan makhluk hidup lain, oleh karena itu akal manusia harus diasah melalui kegiatan belajar. Secara sederhana, belajar dapat diartikan sebagai suatu kegiatan yang melibatkan berbagai potensi pada diri siswa baik fisik, nonfisik, emosi, dan intelektual, serta interaksi antara stimulus dengan respon, sehingga mengakibatkan terjadinya perubahan perilaku. Pernyataan ini di dukung oleh pendapat Wahab (2016:18) yang menyatakan bahwa, belajar adalah "semua aktivitas mental atau psikis yang dilakukan oleh seseorang sehingga menimbulkan perubahan tingkah laku yang berbeda antara sesudah belajar dan sebelum belajar".

Belajar yang merupakan proses kegiatan untuk mengubah tingkah laku dari seseorang yang belajar atau subjek belajar, memiliki banyak faktor yang memengaruhi pelaksanaannya. Dari sekian banyak faktor yang berpengaruh, secara garis besar dapat dikelompokkan menjadi faktor intern (dari dalam) diri si subjek belajar dan faktor ekstern (dari luar) diri si subjek belajar (Sardiman, 2016). Faktor intern ini menyangkut faktor-faktor fisiologis dan faktor psikologis dari dalam diri si subjek belajar, seperti keadaan jasmani, motivasi, minat, ingatan, berpikir, bakat, dan sebagainya. Sedangkan faktor ekstern merupakan segala sesuatu yang mempengaruhi kegiatan belajar yang bersumber dari luar diri si subjek belajar, dimana salah satu yang berpengaruh cukup signifikan adalah kurikulum.

Kurikulum merupakan seperangkat rencana dan pengaturan mengenai tujuan, isi dan bahan pelajaran serta cara yang dipergunakan sebagai suatu pedoman penyelenggaraan kegiatan pembelajaran untuk mencapai tujuan pendidikan tertentu (Gunawan, 2016). Dalam pelaksanaan pendidikan di Kota Denpasar, kurikulum yang diterapkan saat ini adalah Kurikulum 2013. Hal ini sesuai dengan kebijakan pemerintah yang tercantum dalam pasal 1 ayat 1 Permendikbud Nomor 57 Tahun 2014 yang menyatakan bahwa, "kurikulum pada Sekolah Dasar/Madrasah Ibtidaiyah yang telah dilaksanakan sejak tahun 2013/2014 disebut Kurikulum 2013 Sekolah Dasar/Madrasah Ibtidaiyah".

Pelaksanaan pembelajaran Kurikulum 2013 pada Sekolah Dasar/Madrasah Ibtidaiyah (SD/MI) dilakukan dengan pendekatan pembelajaran tematik terpadu, kecuali untuk mata pelajaran Matematika, dan Pendidikan Jasmani Olahraga dan Kesehatan (PJOK) sebagai mata pelajaran yang berdiri sendiri untuk kelas IV, V, dan VI (Permendikbud Nomor 24, 2016). Pembelajaran tematik terpadu merupakan pendekatan pembelajaran yang mengintegrasikan berbagai kompetensi dari berbagai mata pelajaran ke dalam suatu tema. Pembelajaran tematik terpadu ini pada dasarnya dirancang dengan tujuan agar dapat lebih mengaktifkan siswa dalam membangun pengetahuannya sendiri melalui pengalaman belajar yang meliputi mengamati, menanya, mengumpulkan informasi, mengasosiasi, dan mengkomunikasikan. Pengalaman belajar tersebut diharapkan dapat memudahkan siswa memahami materi yang dibelajarkan karena dilaksanakan dengan berpedoman pada pengalaman yang telah dimiliki siswa dan lingkungan sekitar sebagai sumber belajar. Dengan pendekatan tematik terpadu diharapkan pembelajaran dapat terlaksana dengan interaktif dan inspiratif, menyenangkan, menantang, dan memotivasi peserta didik untuk berpartisipasi aktif, kontekstual dan kolaboratif, dapat memberikan ruang yang cukup bagi prakarsa, kreativitas, dan kemandirian peserta didik, serta sesuai dengan bakat, minat, kemampuan dan perkembangan fisik maupun psikologis peserta didik (Permendikbud Nomor 103, 2014). 
Berbagai harapan dan tujuan dari penerapan Kurikulum 2013 tersebut pada kenyataannya belum mampu terealisasikan secara optimal seluruhnya karena dalam penerapannya cukup banyak mengalami kendala, khususnya ketika guru melaksanakan pembelajaran secara terpadu. Wahidmurni (2017), menunjukkan prioritas permasalahan yang dihadapi guru dalam melaksanakan pembelajaran terpadu, khususnya pada mata pembelajaran IImu Pengetahuan Sosial (IPS) terpadu meliputi kurangnya pemahaman tentang cara mengembangkan materi IPS secara terpadu, kurangnya pemahaman tentang konsep pembelajaran IPS terpadu, kemampuan untuk menerapkan metode pembelajaran, kemampuan dalam melaksanakan penilaian pembelajaran, dan kurangnya kemampuan siswa dalam menyampaikan pendapat.

Berdasarkan data rekapitulasi nilai rapor siswa kelas $V$ pada semester satu di SD Negeri Gugus Ir. Soekarno Kecamatan Denpasar Selatan tahun pelajaran 2017/2018 yang diperoleh saat dilaksanakan observasi pada hari Sabtu, 6 Januari 2018, dapat diketahui bahwa persentase rata-rata daya serap siswa terhadap muatan materi mata pelajaran IPS belum optimal, yaitu sebesar $80,5 \%$ dengan rata-rata nilai 80,7 . Data di atas tentunya merupakan sebuah permasalahan tambahan dalam pelaksanaan Kurikulum 2013, khususnya bagi mata pelajaran IPS yang pada hakekatnya merupakan mata pelajaran dasar dari seluruh jenjang pendidikan persekolahan (Gunawan, 2016).

IPS sebagai suatu ilmu pengetahuan mencakup kajian berbagai aspek kehidupan yang majemuk baik hubungan sosial, ekonomi, psikologi, budaya, sejarah, maupun politik. Pendidikan IPS dikembangkan dalam rangka meningkatkan kualitas sumber daya manusia di bidang sikap, pengetahuan, serta keterampilan yang berpijak pada kehidupan masyarakat secara umum. Di dalam pembelajaran IPS sesuai pedoman Kurikulum 2013, sikap, pengetahuan, dan keterampilan tersebut dikategorikan sebagai tingkat kemampuan untuk mencapai standar kompetensi lulusan yang harus dimiliki oleh siswa, yang diistilahkan sebagai kompetensi inti yang terdiri atas kompetensi inti sikap spiritual, kompetensi inti sikap sosial, kompetensi inti pengetahuan, dan kompetensi inti keterampilan (Permendikbud Nomor 57, 2014).

Permasalahan belum optimalnya nilai kompetensi inti pengetahuan siswa terhadap materi mata pelajaran IPS seperti yang dipaparkan tersebut dapat disebabkan karena ada suatu pemahaman yang salah dengan menyatakan IPS sebagai pelajaran yang cenderung bersifat hafalan (Wahidmurni, 2017), sehingga IPS masih sering dibelajarkan dengan menerapkan metode pembelajaran yang lebih menekankan pada keaktifan guru, bukan keaktifan siswa. Selain itu, pemberian tes di akhir pembelajaran juga hanya bersifat mengingat kembali informasi yang telah dipelajari sebelumnya tanpa memberikan kesempatan kepada siswa untuk dapat berpikir dan mengembangkan gagasannya secara lebih mendalam melalui permasalahan-permasalahan yang disajikan, sehingga akibatnya siswa mengalami kesulitan untuk mengembangkan potensi yang dimiliki.

Usaha dalam mengembangkan potensi siswa perlu dilakukan dengan menerapkan model pembelajaran yang diharapkan dapat meningkatkan kemampuan siswa dalam memahami materi pelajaran. Sebagai bentuk respon terhadap kondisi ini, pemerintah telah menerapkan model-model pembelajaran yang sifatnya inovatif dan konstruktif, seperti model pembelajaran Inquiry, Discovery, Project Based Learning, dan Problem Based Learning dalam pembelajaran Kurikulum 2013. Demi kelancaran penerapan model-model pembelajaran tersebut, siswa dituntut untuk memiliki bekal berupa kemampuan berpikir yang baik agar dapat mengikuti kegiatan pembelajaran secara maksimal. Kemampuan berpikir yang sepatutnya saat ini dikembangkan kepada siswa tidak lagi hanya terbatas pada kemampuan berpikir dasar, melainkan juga sangat diperlukan untuk mengembangkan kemampuan berpikir tingkat tinggi siswa. Kemampuan berpikir dasar terbatas pada hal-hal rutin dan bersifat mekanis, misalnya menghafal dan mengulang informasi yang pernah diperolehnya, sedangkan kemampuan berpikir tingkat tinggi meliputi kemampuan pemecahan masalah, pengambilan keputusan, berpikir kritis dan berpikir kreatif (Mahmuzah, 2015).

Berpikir kritis sebagai salah satu kemampuan berpikir tingkat tinggi perlu diupayakan sejak usia dini agar siswa memiliki kemampuan berpikir yang baik dan mampu mencari solusi 
berbagai permasalahan, baik pada kompetensi inti pengetahuan IPS maupun masalah dalam kehidupan sehari-hari yang semakin kompleks. Dengan semakin tingginya kemampuan berpikir kritis siswa ini, diharapkan akan dapat meningkatkan hasil belajar atau penguasaan kompetensi inti pengetahuan siswa, seperti yang dinyatakan oleh Wahab (2016), bahwa berpikir itu sangat berpengaruh terhadap hasil belajar. Lebih lanjut dikemukakan oleh Muhfahroyin (2009) kemampuan berpikir kritis sangat perlu dikembangkan karena (1) pengetahuan yang didasarkan pada hafalan telah didiskreditkan dengan timbulnya anggapan bahwa individu tidak akan dapat menyimpan ilmu pengetahuan dalam ingatan untuk penggunaan yang akan datang, (2) informasi menyebar begitu pesat sehingga setiap individu memerlukan kemampuan agar dapat mengenali macam-macam permasalahan dalam konteks yang berbeda pada waktu yang berbeda pula, (3) kompleksitas pekerjaan modern menuntut adanya individu yang mampu menunjukkan pemahaman terhadap informasi sehingga mampu membuat keputusan dalam dunia kerja, dan (4) masyarakat modern membutuhkan individu untuk menggabungkan informasi yang berasal dari berbagai sumber dan membuat keputusan.

Berdasarkan teori tentang peranan kemampuan berpikir kritis dalam meningkatkan pemahaman dan hasil belajar siswa di atas, maka penelitian ini dilakukan untuk mengetahui hubungan antara kemampuan berpikir kritis dengan penguasaan kompetensi inti pengetahuan IPS, penelitian ini akan dilakukan dengan judul "Korelasi Antara Kemampuan Berpikir Kritis dengan Penguasaan Kompetensi Inti Pengetahuan IPS Siswa Kelas V SD Gugus Ir. Soekarno Kecamatan Denpasar Selatan Tahun Pelajaran 2017/2018".

Tujuan penelitian ini adalah untuk mengetahui korelasi yang signifikan antara kemampuan berkipir kritis dengan penguasaan kompetensi inti pengetahuan IPS siswa kelas $\mathrm{V}$ SD Gugus Ir. Soekarno Kecamatan Denpasar Selatan tahun pelajaran 2017/2018. Lebih lanjut, penelitian ini diharapkan dapat memberikan kontribusi yang positif terhadap ilmu pendidikan, khususnya pendidikan guru sekolah dasar sehingga dapat memperluas pengetahuan tentang strategi atau pendekatan dalam proses pembelajaran.

\section{Metode}

Penelitian ini dilaksanakan pada siswa kelas V SD di Gugus Ir. Soekarno Kecamatan Denpasar Selatan yang terdiri dari SD Negeri 2 Pedungan (kelas VA dan VB), SD Negeri 5 Pedungan (kelas VA, VB, dan VC), SD Negeri 7 Pedungan (kelas VA dan VB), dan SD Negeri 10 Pedungan (kelas V). Penelitian ini dilaksanakan pada semester dua tahun pelajaran 2017/2018 dari bulan Januari, Pebruari, hingga Maret tahun 2018.

Penelitian ini menggunakan rancangan penelitian ex post facto. Penelitian ex post facto merupakan "pendekatan pada subjek penelitian untuk meneliti yang telah dimiliki oleh subjek penelitian secara wajar tanpa adanya usaha sengaja memberikan perlakuan untuk memunculkan variabel lain yang ingin diteliti" (Dantes, 2012:59).

Rancangan penelitian ex post facto terdiri atas dua jenis, yaitu studi korelasi dan studi komparatif grup, dan dalam penelitian ini, jenis studi yang digunakan adalah studi korelasi. Menurut Agung (2016:123), korelasi adalah "hubungan yang bersifat asosiatif". Kemudian dikemukakan bahwa korelasi adalah "suatu bentuk analisis data dalam penelitian yang bertujuan untuk mengetahui kekuatan atau bentuk arah hubungan di antara dua variabel atau lebih, dan besarnya pengaruh yang disebabkan oleh variabel yang satu (variabel bebas) terhadap variabel lainnya (variabel terikat)" Siregar (2017:200). Lebih lanjut Dantes (2012:73) manyatakan, "studi korelasi digunakan untuk menentukan sejauh mana dua variabel atau lebih berhubungan". Oleh karena itu, dapat dirangkum bahwa korelasi merupakan suatu bentuk studi dari penelitian dengan rancangan ex post facto yang digunakan untuk menyatakan kekuatan dan bentuk hubungan antar variabel penelitian.

Besar kecilnya hubungan antar variabel dalam penelitian korelasional ditentukan melalui pengunaan koefisien korelasi. Agung (2016:124) manyatakan bahwa koefisien korelasi adalah "suatu angka yang menunjukkan ukuran kuantitas hubungan/korelasi antar variabel yang dikorelasikan". Selanjutnya, Siregar (2017) menyatakan bahwa koefisien korelasi atau yang diistilahkan dengan ( $r$ ) adalah bilangan yang menyatakan kekuatan hubungan antara dua 
variabel atau lebih atau juga dapat menentukan arah dari kedua variabel. Berdasarkan kedua pendapat tersebut, dapat dipahami bahwa koefisien korelasi adalah angka yang menunjukkan kekuatan hubungan dan arah hubungan di antara dua variabel atau lebih.

Penelitian ex post facto dengan studi korelasi yang dilaksanakan ini bertujuan untuk mencari hubungan dua variabel, yaitu variabel bebas $(X)$ dan variabel terikat $(Y)$ tanpa memberikan perlakukan terhadap variabel-variabel tersebut. Variabel bebas yang dalam penelitian ini adalah kemampuan berpikir kritis, sedangkan variabel terikatnya adalah penguasaan kompetensi inti pengetahuan IPS.

Teknik Korelasi yang digunakan dalam penelitian ini yaitu, teknik korelasi product moment. Menurut Agung (2016:125) "teknik korelasi product moment berfungsi menghitung koefisien korelasi antara variabel bebas interval (skor) dengan variabel terikat interval (skor) lainnya. Korelasi yang dilakukan hanya menghubungkan antara dua variabel. Sifat hubungan tersebut adalah asimetris (satu arah) $(X \rightarrow Y$ )". Sedangkan menurut Supardi (2016) product moment digunakan untuk data interval dengan data interval. Jadi dapat dirangkum bahwa teknik korelasi product moment merupakan teknik korelasi yang digunakan untuk menghitung hubungan antara variabel bebas dan variabel terikat secara interval.

Dalam suatu penelitian, diperlukan adanya populasi sebagai individu yang diteliti. Populasi didefinisikan sebagai sejumlah kasus yang bisa berbentuk peristiwa-peristiwa, manusia, hewan, tumbuh-tumbuhan dan sebagainya yang memenuhi seperangkat kriteria tertentu yang ditentukan peneliti (Dantes, 2012). Lebih lanjut, Sugiyono (2009:117) meyatakan "populasi bukan hanya orang, tetapi juga obyek dan benda-benda lain. Populasi juga bukan sekedar jumlah yang ada pada objek/subjek yang dipelajari, tetapi meliputi seluruh karakteristik/sifat yang dimiliki oleh subjek atau obyek itu". Berdasarkan penjelasan tersebut, maka dapat dirangkum bahwa populasi merupakan keseluruhan subjek yang terlibat dalam suatu penelitian yang mempunyai karakteristik tertentu dimana tidak hanya orang, tetapi juga benda-benda lain yang menjadi sumber pengambilan sampel penelitian. Dalam penelitian ini, yang dijadikan sebagai populasi adalah seluruh siswa kelas V di SD Negeri Gugus Ir. Soekarno Kecamatan Denpasar Selatan pada tahun pelajaran 2017/2018 yang berjumlah 325 orang siswa. Dalam penelitian ini selain diperlukan adanya populasi, juga diperlukan adanya sampel yang akan diteliti. Setyosari (2015:221) menyatakan sampel "adalah suatu kelompok lebih kecil atau bagian dari populasi secara keseluruhan". Lebih lanjut, Agung (2014:69) menyatakan sampel adalah "bagian dari populasi yang diambil, yang dianggap mewakili seluruh populasi dan diambil dengan menggunakan teknik tertentu". Berdasarkan ketiga pendapat tersebut dapat dirangkum bahwa sampel adalah merupakan bagian dari populasi dengan jumlah tertentu yang diambil berdasarkan suatu teknik.

Untuk menentukan jumlah anggota sampel dapat dilihat dari tabel Isaac dan Michael. Untuk jenis penelitian yang dilaksanakan dalam bidang sosial, seperti bidang pendidikan, taraf kesalahan yang digunakan adalah $5 \%$ karena subjek yang diteliti dalam penelitian pendidikan sulit untuk dikontrol secara penuh, sehingga masih dapat ditolerir tingkat kesalahannya sebesar 5\%. Berdasarkan data dari tabel tersebut, dengan populasi siswa kelas V SD Negeri di Gugus Ir. Soekarno pada tahun pelajaran 2017/2018 yang berjumlah 325 orang siswa dapat diketahui jumlah sampel penelitian dengan taraf kesalahan $5 \%$ adalah 167 orang siswa.

Setelah diketahui jumlah sampel keseluran berdasarkan tabel Isaac dan Michael, selanjutnya perlu ditentukan jumlah sampel yang akan dipilih pada masing-masing sekolah dengan menggunakan teknik proportional random sampling. Menurut Agung (2014), proportional random sampling (sampel proporsional/sampel berimbang) merupakan teknik sampling yang dilakukan untuk lebih menjamin representatifnya sampel jika ternyata subjek yang terdapat dalam tiap kelas atau tiap wilayah tidak sama. Teknik sampling ini dilakukan dengan cara mengambil individu yang terdapat dalam masing-masing kategori populasi, sesuai dengan proporsi atau perimbangan untuk dijadikan sampel penelitian. Berdasarkan penghitungan dengan menggunakan rumus proportional random sampling tersebut, maka dapat ditentukan banyaknya siswa yang akan dijadikan sampel dalam penelitian adalah 169 orang siswa. 
Data yang dikumpulkan dalam penelitian ini adalah data kemampuan berpikir kritis dan penguasaan kompetensi inti pengetahuan IPS siswa kelas V SD Gugus Ir. Soekarno Kecamatan Denpasar Selatan tahun pelajaran 2017/2018. Metode pengumpulan data dalam penelitian ini menggunakan metode tes dan nontes. Metode tes digunakan untuk mengumpulkan data kemampuan berpikir kritis siswa yang dilakukan dengan menggunakan instrumen tes uraian bentuk terbuka atau bebas yang diberikan kepada siswa yang terpilih sebagai sampel penelitian. Sedangkan data penguasaan kompetensi inti pengetahuan IPS dikumpulkan dengan metode nontes melalui teknik pencatatan dokumen terhadap nilai Ulangan Akhir Semester (UAS) kompetensi inti pengetahuan IPS siswa kelas V SD Negeri Gugus Ir. Soekarno Kecamatan Denpasar Selatan tahun pelajaran 2017/2018 pada semester satu yang dijadikan sampel penelitian.

Sebelum tes diberikan kepada siswa, terlebih dahulu tes uraian kemampuan berpikir kritis harus diuji coba untuk mendapatkan gambaran secara teoretik apakah instrumen layak digunakan atau tidak. Selanjutnya setelah tes diuji coba, barulah kemudian dilakukan pengujian validitas dan reliablitas.

Dalam penelitian ini, uji validitas dilakukan menggunakan uji validitas isi dengan mencocokan antara butir tes dengan indikator pencapaian hasil belajar IPS pada tema enam dan indikator kemampuan berpikir kritis. Selanjutnya, setelah butir-butir tes sesuai dengan indikator dilakukan pertimbangan atau dikonsultasikan dengan ahli isi. Selain uji validitas isi, instrumen yang digunakan juga diuji validitas butirnya dengan menggunakan rumus product moment. Adapun untuk uji reliabilitas instrumen, dilakukan dengan menggunakan rumus Alpha Cronbach.

Setelah didapatkan data kemampuan berpikir kritis dan penguasaan kompetensi inti pengetahuan IPS siswa, data tersebut selanjutnya akan di analisis dengan menggunakan statistik deskriptif dan statistik inferensial. Menurut Supardi (2016:3) statistik deskriptif merupakan "bagian dari statistik yang mempelajari cara pengumpulan data dan penyajian data sehingga mudah dipahami". Lebih lanjut dinyatakan bahwa statistik deskriptif merupakan "statistik yang berfungsi untuk mendeskripsikan atau memberi gambaran terhadap obyek yang diteliti melalui data sampel atau populasi sebagaimana adanya, tanpa melakukan analisis dan membuat kesimpulan yang berlaku untuk umum" (Sugiyono, 2009:29). Berdasarkan dua pendapat tersebut dapat dirangkum bahwa statistik deskriptif merupakan metode statistik yang mempelajari cara pengumpulan dan penyajian data untuk mendeskripsikan obyek yang diteliti tanpa melakukan analisis dan membuat kesimpulan yang berlaku untuk umum. Pada statistik deskriptif ini data akan disajikan untuk mengetahui nilai rata-rata (mean), nilai dengan frekuensi tertinggi (modus), nilai tengah (median), dan standar deviasi.

Adapun metode analisis statistik inferensial ialah "suatu cara pengolahan data yang dilakukan dengan jalan menerapkan rumus-rumus statistik inferensial untuk menguji suatu hipotesis penelitian yang diajukan peneliti, dan kesimpulan ditarik berdasarkan pengujian terhadap hipotesis" (Agung, 2014:110). Supardi (2016) menyatakan statistik inferensial adalah "bagian dari statistik yang mempelajari mengenai penafsiran dan penarikan kesimpulan yang berlaku secara umum dari data sampel yang tersedia. Jadi, dapat dirangkum bahwa metode analisis statistik inferesial adalah cara pengolahan data untuk melakukan penafsiran atau penarikan kesimpulan dari data sampel yang akan diberlakukan secara umum.

Pada penelitian ini, sebelum dilaksanakan pengujian hipotesis terlebih dahulu dilakukan uji prasyarat menggunakan uji normalitas dengan rumus chi-kuadrat $\left(\mathrm{x}^{2}\right)$. Adapun kriteria pengujiannya adalah nilai $x^{2}$ tabel dengan $x^{2}$ hitung pada taraf signifikan $5 \%$ (dk = jumlah kelas interval ( $k$ ) dikurangi 1 ), dengan ketentuan apabila $x^{2}$ nitung $<x^{2}$ tabel, maka data berdistribusi normal, begitu pula sebaliknya apabila $x^{2}{ }_{\text {nitung }} \geq x^{2}$ tabel, maka data tidak berdistribusi normal.

Setelah dilakukan analisis dan diketahui sebaran data berdistribusi normal, maka analisis dilanjutkan untuk menguji hipotesis menggunakan statistik parametrik dengan menggunakan rumus product moment $\left(r_{x y}\right)$. Kriteria pengujian yang digunakan untuk membandingkan nilai $r_{x y}$ hitung dengan $r_{x y}$ tabel. Apabila nilai $r_{x y}$ hitung $>$ nilai $r_{x y}$ tabel pada taraf signifikansi $5 \%$, dengan $N=$ 169, maka $\mathrm{H}_{0}$ yang menyatakan tidak terdapat korelasi yang signifikan antara kemampuan berpikir kritis dengan penguasaan kompetensi inti pengetahuan IPS siswa kelas V SD Gugus 
Ir. Soekarno Kecamatan Denpasar Selatan tahun pelajaran 2017/2018 ditolak. Namun apabila nilai $r_{x y}$ hitung $\leq$ nilai $r_{x y}$ tabel, maka $\mathrm{H}_{0}$ diterima.

\section{Hasil dan Pembahasan}

Berdasarkan analisis deskriptif data kemampuan berpikir kritis siswa dapat diketahui bahwa skor maksimum $(X t)=87,5$, nilai minimum $(X r)=35$, mean $=64,01$, modus $=60,17$, median $=62,78$, dan standar deviasi $=11,13$. Data kemampuan berpikir kritis tersebut juga disajikan dalam bentuk histogram sebagai berikut.

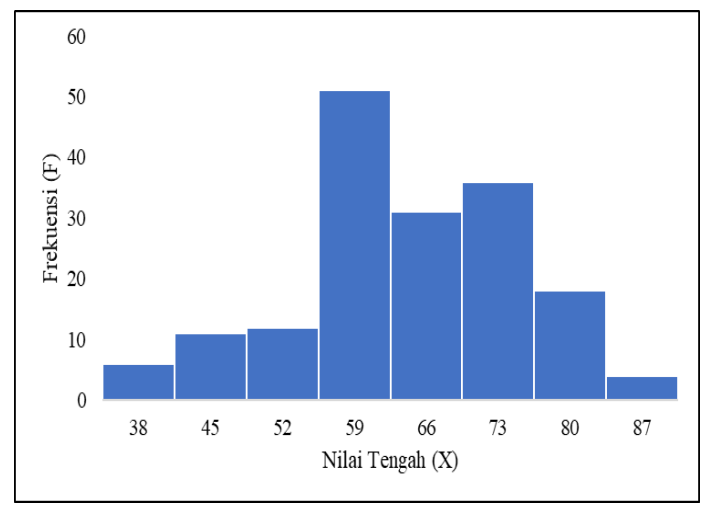

\section{Gambar 1 Histogram Data Kemampuan Berpikir Kritis Siswa Kelas V SD}

Berdasarkan analisis deskriptif data penguasaan kompetensi inti pengetahuan IPS siswa dapat diketahui bahwa skor maksimum $(X t)=97$, nilai minimum $(X r)=70$, mean $=83,54$, modus $=87,18$, median $=83,54$, dan standar deviasi $=5,95$. Data penguasaan kompetensi inti pengetahuan IPS tersebut juga disajikan dalam bentuk histogram sebagai berikut.

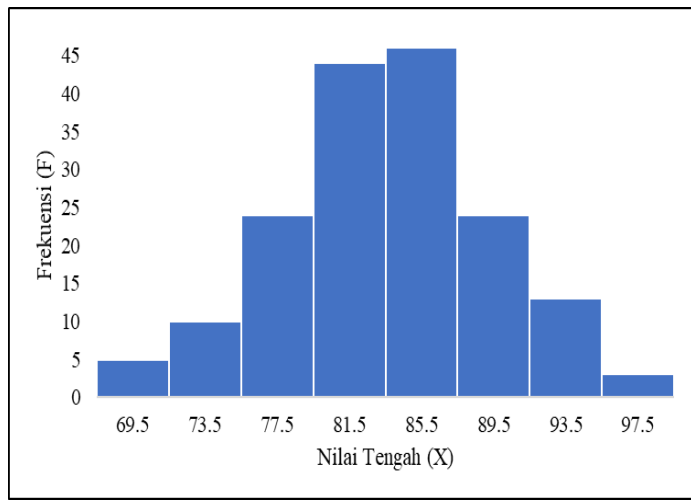

Gambar 2 Histogram Data Penguasaan Kompetensi Inti Pengetahuan IPS Siswa Kelas V SD

Setelah diketahui sebaran dari data kemampuan berpikir kritis dan penguasaan kompetensi inti pengetahuan IPS tersebut, data selanjutnya diuji normalitas sebaran datanya agar dapat diketahui sebaran data tersebut berdistribusi normal atau tidak. Berdasarkan analisis dengan menggunakan rumus Chi-kuadrat dapat diketahui nilai $x^{2}$ nitung $=6,135$, dan menggunanakan taraf signifikansi $5 \%$ dengan menggunakan derajat kebebasan 5 , maka diperoleh $x^{2}$ tabel $=11,070$. Hal ini berarti $x^{2}$ hitung $=6,135<x^{2}$ tabel $=11,070$. Jadi, dapat disimpulkan bahwa $\mathrm{H}_{0}$ diterima, ini berarti sebaran data kemampuan berpikir kritis siswa berdistribusi normal. Sedangkan hasil analisis terhadap data penguasaan kompetensi inti pengetahuan IPS dengan menggunakan rumus Chi-kuadrat dapat diketahui nilai $\mathrm{x}^{2}{ }_{\text {hitung }}=$ 
9,412, dan menggunanakan taraf signifikansi 5\% dengan menggunakan derajat kebebasan 5 , maka diperoleh $x^{2}$ tabel $=11,070$. Hal ini berarti $x^{2}$ hitung $=9,412<x^{2}$ tabel $=11,070$. Jadi, dapat disimpulkan bahwa $\mathrm{H}_{0}$ diterima, ini berarti sebaran data penguasaan kompetensi inti pengetahuan IPS siswa berdistribusi normal.

Berdasarkan hasil uji normalitas sebaran data yang didapatkan hasil bahwa kedua data (data kemampuan berpikir kritis dan penguasaan kompetensi inti pengetahuan IPS) berdistribusi normal, oleh karena itu dapat dilakukan uji hipotesis menggunakan rumus product moment dengan hasil $r_{x y}$ hitung $=0,342$. Lebih lanjut untuk menguji signifikansi koefisien korelasi, digunakan nilai tabel product moment ( $r_{x y}$ tabel $)$ untuk $N=169$ pada taraf signifikansi $5 \%=0,148$ sebagai pembanding, sehingga dapat dinyatakan $r_{x y}$ hitung $=0,324>r_{x y}$ tabel $=0,148$. Ini berarti nilai $r_{x y}$ hitung $=0,342$ signifikan, sehingga $\mathrm{H}_{0}$ yang menyatakan tidak terdapat korelasi yang signifikan antara kemampuan berpikir kritis dengan penguasaan kompetensi inti pengetahun IPS siswa kelas V SD Gugus Ir. Soerkarno Kecamatan Denpasar Selatan tahun pelajaran 2017/2018 ditolak, dan $\mathrm{H}_{\mathrm{a}}$ diterima.

Berdasarkan nilai $r_{x y}$ hitung tersebut dapat ditunjukkan bahwa terjadi korelasi dengan tingkat hubungan yang lemah dan dalam bentuk positif antara kemampuan berpikir kritis dengan penguasaan kompetensi inti pengetahuan IPS siswa kelas V di SD Gugus Ir. Soekarno Kecamatan Denpasar Selatan tahun pelajaran 2017/2018. Lebih lanjut, berdasarkan nilai koefisien korelasi $\left(r_{x y}\right.$ hitung $\left.=0,342\right)$ dapat ditentukan nilai koefisien determinasinya $=r^{2}=0,342^{2}$ $=0,12$. Ini berarti varians yang terjadi pada variabel penguasaan komptensi inti pengetahuan IPS $12 \%$ dapat dijelaskan melalui varians yang terjadi pada variabel kemampuan berpikir kritis, atau penguasaan kompetensi inti pengetahuan IPS 12\% ditentukan oleh besarnya kemampuan berpikir kritis, dan $88 \%$ oleh faktor lain. Hal tersebut dapat diinterpretasikan bahwa bahwa ratarata siswa yang tergolong telah memiliki kemampuan berpikir kritis, mampu memiliki penguasaan terhadap kompetensi inti pengetahuan IPS yang lebih tinggi daripada siswa yang belum memiliki kemampuan berpikir kritis.

Interpretasi tersebut dapat diartikan bahwa semakin tinggi kemampuan berpikir kritis siswa, maka siswa tersebut akan lebih mampu dalam memahami muatan materi mata pelajaran IPS, serta lebih mampu untuk mengambil keputusan yang dapat dipercaya terhadap permasalahan yang timbul dalam belajar, khususnya dalam belajar IPS. Hal ini sesuai dengan pendapat Wahab (2016) yang menyatakan bahwa kemampuan berpikir kritis sangat berpengaruh terhadap hasil belajar siswa, serta sesuai dengan pendapat Fristadi dan Bharata (2015), yang menyatakan bahwa berpikir kritis merupakan usaha untuk mengumpulkan, menginterpretasi, menganalisis, dan mengevaluasi dengan tujuan untuk mengambil keputusan yang dapat dipercaya dan valid.

Keberhasilan siswa dalam menguasai kompetensi inti pengetahuan IPS salah satuya dipengaruhi oleh kemampuan bepikir, khususnya kemampuan berpikir kritis siswa. Kemampuan berpikir kritis akan membantu mempersiapkan siswa menjadi pemecah masalah yang tangguh, pembuat keputusan yang matang, dan orang yang tidak pernah berhenti belajar. Sangat penting bagi siswa mejadi seorang pemikir yang kritis karena seiring dengan meningkatnya jenis pekerjaan dimasa mendatang akan selalu dibutuhkan individu yang handal yang memiliki kemampuan berpikir kritis. Hal tersebut sejalan dengan pendapat Fatmawati, dkk (2014), yang menyatakan berpikir kritis sangat diperlukan oleh setiap orang untuk menyikapi permasalahan dalam kehidupan yang nyata.

Kemampuan berpikir kritis tidak akan tumbuh begitu saja, oleh karena itu sepatutnya dikembangkan sejak usia dini. Pengembangan kemampuan berpikir kritis tidak hanya dapat dilakukan di lingkungan sekolah, melainkan juga dapat dan perlu dilakukan di lingkungan keluarga dan masyarakat. Dengan demikian diharapkan kemampuan berpikir kritis akan dapat berkembang pada diri setiap anak.

Sebagai implikasi dari hasil penelitian ini dalam melaksanakan kegiatan pembelajaran, utamanya dalam pembelajaran IPS, guru sebaiknya mampu untuk meningkatkan kemampuan berpikir kritis siswa. Guru harus berusaha meminimalisir terjadinya kegiatan pembelajaran yang berpusat pada guru dan diharapkan agar mampu melaksanakan kegiatan pembelajaran yang lebih mengaktifkan siswa untuk ikut terlibat langsung dalam kegiatan pembelajaran melalui 
upaya belajar yang terjadi secara kontekstual. Oleh karena itu, diharapkan siswa tidak lagi hanya belajar dengan tujuan menghafal materi, melainkan belajar untuk memahami materi dan berbagai fenomena-fenomena yang terjadi secara nyata di lingkungan masyarakat.

Siswa yang memiliki kemampuan berpikir kritis diharapkan mampu membuat keputusan yang baik berdasarkan pertimbangan yang logis sesuai dengan situasi dan kondisi yang terjadi. Melalui siswa yang memiliki kemampuan berpikir kritis, nantinya siswa juga akan mampu memiliki penguasaan yang lebih baik terhadap kompetensi inti pengetahuan IPS, serta akan mampu pula memberikan sumbangsih terhadap keluarga maupun masyarakat berdasarkan kemampuan berpikir kritis yang dimilikinya.

\section{Simpulan dan Saran}

Berdasarkan analisis yang telah dilakukan dengan menggunakan rumus product moment didapatkan hasil $r_{x y \text { hitung }}=0,342$ dan $r_{x y}$ tabel $=0,148$ yang berarti $r_{x y}$ hitung $>r_{x y}$ tabel, sehingga $H_{a}$ yang menyatakan terdapat korelasi yang signifikan antara kemampuan berpikir kritis dengan penguasaan kompetensi inti pengetahuan IPS siswa kelas V SD Gugus Ir. Soekarno Kecamatan Denpasar Selatan tahun pelajaran 2017/2018 diterima. Nilai $r_{x y}$ hitung $=0,342$ tersebut juga menunjukkan bahwa terjadi korelasi yang positif dalam tingkat yang lemah antara kemampuan berpikir kritis dengan penguasaan kompetensi inti pengetahuan IPS.

Berdasarkan hasil analisis tersebut dapat diinterpretasikan bahwa, rata-rata siswa yang tergolong memiliki kemampuan berpikir kritis, memiliki penguasaan terhadap kompetensi inti pengetahuan IPS yang lebih tinggi daripada siswa yang belum memiliki kemampuan berpikir kritis. Oleh karena itu dapat disimpulkan bahwa, semakin tinggi kemampuan berpikir kritis yang dimiliki siswa, maka semakin tinggi pula penguasaan siswa terhadap kompetensi inti pengetahuan IPS.

Berdasarkan simpulan tersebut, maka dapat disampaikan saran-saran yang ditujukan kepada siswa agar lebih intensif dalam melatih kemampuan berpikirnya, khususnya kemampuan berpikir kritis dengan secara bersungguh-sungguh belajar untuk dapat memahami materi pembelajaran dengan baik dan membiasakan diri untuk belajar membuat keputusan yang didukung oleh data-data yang diperoleh melalui kegiatan mengumpulkan, dan menganalisis informasi sehingga dapat diambil keputusan yang dapat dipercaya dan valid; guru agar dapat memberikan pembelajaran yang inovatif dan konstruktif, guru juga disarankan agar meminimalisir pemberian soal yang tujuannya hanya untuk mengingat dan mengulang materi pembelajaran; kepala sekolah agar dapat menggunakan hasil penelitian ini sebagai pendukung sumber belajar guru dalam meningkatkan kualitas pembelajaran dengan menumbuhkan kemampuan berpikir kritis siswa dalam belajar di sekolah sehingga sekolah mampu menghasilkan siswa yang berkualitas; peneliti agar hasil penelitian ini digunakan sebagai referensi untuk melaksanakan penelitian selanjutnya atau menemukan inovasi untuk meningkatkan pelaksanaan kegiatan pembelajaran yang bermakna dan mampu mengoptimalkan kemampuan siswa.

\section{Daftar Pustaka}

Agung, A. A. G. 2014. Buku Ajar Metodologi Penelitian Pendidikan. Malang: Aditya Media Publishing.

Agung, A. A. G. 2016. Stastistik Dasar Untuk Pendidikan. Yogyakarta: Deepublish.

Dantes, N. 2012. Metode Penelitian. Yogyakarta: Andi Yogyakarta.

Dwijananti, P. and Yulianti, D., 2010. Pengembangan kemampuan berpikir kritis mahasiswa melalui pembelajaran problem based instruction pada mata kuliah fisika lingkungan. Jurnal Pendidikan Fisika Indonesia, 6(2). 
Fatmawati, dkk. (2014). "Analisis Berpikir Kritis Siswa dalam Pemecahan Masalah Matematika Berdasarkan Polya Pada Pokok Bahasan Persamaan Kuadrat". Jurnal FKIP UNS, Volume 2, Nomor 9 (hlm.913). Tersedia pada http: http://eprints. walisongo.ac.id/5915/1/123511090.pdf (diakses tanggal 7 Januari 2018).

Fakhriyah, F., 2014. Penerapan Problem Based Learning dalam Upaya Mengembangkan Kemampuan Berpikir Kritis Mahasiswa. Jurnal Pendidikan IPA Indonesia, 3(1).

Fristadi, R. dan Bharata, H. 2015. "Meningkatkan Kemampuan Berpikir Kritis Siswa Dengan Problem Based Learning". Jurnal Seminar UNY, Volume 2, Nomor 7 (hlm.597). Tersedia pada http://seminar. uny.ac. id/semnasmatematika/sites/seminar.uny.ac.id.semnasmatematika/files/banner/PM-86.pdf (diakses tanggal 7 Januari 2018).

Gunawan, R. 2016. Pendidikan IPS Filosofi, Konsep dan Aplikasi. Bandung: Alfabeta.

Karim, A., 2011. Penerapan metode penemuan terbimbing dalam pembelajaran matematika untuk meningkatkan pemahaman konsep dan kemampuan berpikir kritis siswa sekolah dasar. Jurnal Pendidikan, 1(1), pp.21-32.

Mahmuzah, R. 2015. "Peningkatan Kemampuan Berpikir Kritis Matematis Siswa SMP Melalui Pendekatan Problem Possing". Jurnal Unsyiah, Volume 4, Nomor 1 (hlm,65). Tersedia pada http://jurnal.unsyiah.ac.id/peluan g/article/view/5860 (diakses tanggal 7 Januari 2018).

Muhfahroyin. 2009. "Memberdayakan Kemampuan Berpikir Kritis Siswa Melalui Pembelajaran Konstruktivistik". Jurnal Pendidikan dan Pembelajaran UM, Volume 16, Nomor 1 (hlm.89). Tersedia pada http://journal.um.ac.id/ index.php/pendidikan-danpembelajara n/article/view/2611 (diakses tanggal 7 Januari 2018).

Permendikbud Nomor 57 Tahun 2014 tentang Kurikulum 2013 Sekolah Dasar/Madrasah Ibtidaiyah, 2014. Jakarta: Departemen Pendidikan dan Kebudayaan.

Permendikbud Nomor 103 Tahun 2014 tentang Pembelajaran Pada Pendidikan Dasar dan Pendidikan Menengah, 2014. Jakarta: Departemen Pendidikan dan Kebudayaan.

Permendikbud Nomor 24 Tahun 2016 tentang Kompetensi Inti dan Kompetensi Dasar Pelajaran dalam Kurikulum 2013 Pada Pendidikan Dasar dan Pendidikan Menengah, 2016. Jakarta: Departemen Pendidikan dan Kebudayaan.

Sardiman. 2016. Interaksi \& Motivasi Belajar Mengajar. Jakarta: Rajawali Pers.

Setyosari, P.A. 2015. Metode Penelitian Pendidikan. Jakarta: Prenadamedia Group.

Setyowati, A. and Subali, B., 2011. Implementasi pendekatan konflik kognitif dalam pembelajaran fisika untuk menumbuhkan kemampuan berpikir kritis siswa SMP kelas VIII. Jurnal Pendidikan Fisika Indonesia, 7(2).

Siregar, Syofian. 2017. Statistika Terapan Untuk Perguruan Tinggi. Jakarta: Kencana.

Sugiyono. 2009. Metode Penelitian Pendidikan Pendekatan Kuantitatif, Kualitatif dan R\&D. Bandung: Alfabeta.

Supardi. 2016. Aplikasi Statistika Dalam Penelitian Konsep Statistik Yang Lebih Komprehensif. Jakarta: Change Publication. 
Wahab, Rohmalina. 2016. Psikologi Belajar. Jakarta: Rajawali Pers.

Wahidmurni, H. 2017. Metodologi Pembelajaran IPS Pengembangan Standar Proses Pembelajaran IPS di Sekolah/Madrasah. Yogyakarta: Ar-Ruzz Media. 